\title{
вмJ Global Health Intersectoral policy on industries that produce unhealthy commodities: governing in a new era of the global economy?
}

\author{
Raphael Lencucha (D) , ${ }^{1}$ Anne Marie Thow ${ }^{2}$
}

To cite: Lencucha R, Thow AM. Intersectoral policy on industries that produce unhealthy commodities: governing in a new era of the global economy?BMJ Global Health 2020;5:e002246. doi:10.1136/ bmjgh-2019-002246

Handling editor Eduardo Gómez

Received 18 December 2019 Revised 4 May 2020 Accepted 28 May 2020
A Check for updates

(c) Author(s) (or their employer(s)) 2020. Re-use permitted under CC BY-NC. No commercial re-use. See rights and permissions. Published by BMJ.

${ }^{1}$ School of Physical and Occupational Therapy, Faculty of Medicine, McGill University, Montreal, Quebec, Canada ${ }^{2}$ School of Public Health, Menzies Centre for Health Policy, University of Sydney, Sydney, New South Wales, Australia

Correspondence to Dr Raphael Lencucha; raphael.lencucha@mcgill.ca

\section{ABSTRACT}

Tobacco, alcohol and unhealthy foods are key contributors to non-communicable diseases globally. Public health advocates have been proactive in recent years, developing systems to monitor and mitigate both health harms and influence by these industries. However, establishing and implementating strong government regulation of these unhealthy product-producing industries remains challenging. The relevant regulatory instruments lie not only with ministries of health but with agriculture, finance, industry and trade, largely driven by economic concerns. These policy sectors are often unreceptive to public health imperatives for restrictions on industry, including policies regarding labelling, marketing and excise taxes. Heavily influenced by traditional economic paradigms, they have been more receptive to industry calls for (unfettered) market competition, the rights of consumers to choose and the need for government to allow industry free rein; at most to establish voluntary standards of consumer protection, and certainly not to directly regulate industry products and practices. In recent years, the status quo of a narrow economic rationality that places economic growth above health, environment or other social goals is being re-evaluated by some governments and key international economic agencies, leading to windows of opportunity with the potential to transform how governments approach food, tobacco and alcohol as major, industry-driven risk factors. To take advantage of this window of opportunity, the public health community must work with different sectors of government to(1) reimagine policy mandates, drawing on whole-of-government imperatives for sustainable development, and (2) closely examine the institutional structures and governance processes, in order to create points of leverage for economic policies that also support improved health outcomes.

\section{GAPS IN PROGRESS ON NCD PREVENTION}

Non-communicable diseases (NCDs) remains a pressing and persistent challenge for governments. The toll on quality of life, life expectancy and healthcare costs continue to drain societies' social and monetary resources. A major driver of this challenge is the relentless pursuit of profits by alcohol, processed food

\section{Summary box}

- Tobacco, unhealthy food and alcohol-producing industries remain highly influential in economic sectors of government.

- The influence of these industries is largely conditioned by models of economic growth that have historically neglected social goods such as health and the environment.

- Recent shifts have occurred in approaches to economic policy that reflect a need to address sustainability, health and social well-being.

- These shifts provide an important opportunity for public health to work with the economic sectors of government to redress the harms of these unhealthy commodity-producing industries.

and tobacco industries. ${ }^{1-3}$ Although progress is being made by governments to control these health-harming industries, efforts are often rooted in the implicit policy framework of 'inform the consumer', rather than one that seeks to regulate industry and stimulate healthy product production. ${ }^{4}$ This emphasis on consumer responsibility and behaviour, although an important component of a comprehensive public health approach, has largely been co-opted by industry to shift attention away from their aggressive promotion of unhealthy products. Recent research examining the implementation of NCD prevention policies finds that clinical guidelines, graphic warnings on tobacco packaging and NCD risk factor surveys were the most commonly implemented measures, all of which serve to inform consumer decision, professional response or policy planning rather than regulate industries and products. ${ }^{5}$

At the core of this dynamic is a view that government should balance protection of population health and the freedom of industry to provide 'desirable' consumer products. This dynamic is reflected in the 
tendency of governments to establish voluntary standards for industry self-regulation, particularly when it comes to management of unhealthy foods. ${ }^{6}$ This tendency is rooted in a deeper legacy of neoliberalism, a paradigm that has come to dominate the imagination of policy actors and institutions globally. ${ }^{7}$ This paradigm is reflected in a general shift of responsibility for social well-being from the state to the citizen, underpinned by a foundational assumption that markets, not public policies, are the principal means of creating individual well-being. ${ }^{8}$ The conditions that lead to industry influence and this core belief within government that at most public protection and market freedom should be "balanced" ${ }^{9}$ require concerted attention. ${ }^{10}$

The attention paid by public health advocates (eg, civil servants, civil society, health professionals and/or social movements) to product-producing industries in recent years has led to important policy advances and guidelines to protect health. ${ }^{11} 12$ The WHO has developed strong recommendations drawing from the extensive scholarship on conflicts of interest for unhealthy commodity industries including recent guidelines to protect food and nutrition policies from commercial interests ${ }^{13}$ and recent work with the International Labour Organization to cease tobacco industry funding to the organisation. ${ }^{14}$ The WHO continues to lead the way in establishing guidelines for the regulation of unhealthy food, tobacco and alcohol producers as exemplified by the 2018 launch of the community of practice explicitly linking the commercial determinants of health with NCD prevention. ${ }^{15}$

Despite these advances, strong and direct industry regulation remains hard won. One of the key challenges to regulation is that regulatory mandates are under the purview not just of ministries of health but of economic sectors such as agribusiness, finance, industry and trade. ${ }^{16}$ These sectors often facilitate the ability of these health harming industries to operate within their borders, through the provision of reduced tax rates, access to public infrastructure and other supports. The urgency of addressing policy across sectors is recognised by key international agencies like the United Nations Development Programme (UNDP) who note that "whole-of-government and whole-of-society responses are essential' to address the rise of NCDs. ${ }^{17}$ The argument for the regulation of unhealthy product-producing industries from public health advocates has historically come up against, often exaggerated, ${ }^{18}$ economic arguments within these sectors that highlight the impacts regulation would have on employment and wealth creation. These arguments are often coupled with ideological arguments advancing freedom of choice and the unintended consequences of 'big government'. ${ }^{3}$ These arguments create a situation where public health advocates attempt to frame their arguments in economic terms often moulding messages to fit within existing economic paradigms. Although such framing can have practical utility in the realm of policy advocacy, we suggest that the growing public recognition of the climate crisis, the dramatic and continued rise in inequality, and other social and environmental ills arising from an antisocial capitalism ${ }^{819}$ is destabilising the current economic order and is providing opportunities to more deeply transform the relationship between government, market and society. ${ }^{20}$

We argue in this paper that public health action needs to address the mandates of the economic sector and the institutions that maintain often-conflicting approaches to unhealthy commodities. Now is an opportune time for such action, as a result of significant shifts in economic norms. Recent recognition by international economic agencies such as the International Monetary Fund (IMF) signal that the status quo of a narrow economic rationality that places economic growth above health, environment or other social goals, is being re-evaluated by key international economic agencies, leading to windows of opportunity with the potential to transform how governments approach the three key industry-driven risk factors: tobacco, processed foods and alcohol.

\section{THE PROBLEM WITH THE STATUS-QUO OF ECONOMIC POLICY}

Prescriptions to privatise social services, attract foreigndirect investment and stimulate export-led growth have dominated economic policy for the past 40 years, often with detrimental impacts on population health and environment. ${ }^{21}$ This orientation has discouraged public investment in social services like public healthcare and has led to government support for private investment in unhealthy commodities. This situation has also enhanced the ability of industry to shape the consumer environment, fostering a culture of unhealthy consumption. For example, the lack of government intervention in the advertising and promotion of unhealthy foods to children has propelled the rise in NCDs globally by allowing the industry to promote products largely unrestrained. $^{22} 23$ The growth and influence of global enterprises that produce unhealthy products (eg, Coca Cola, Pepsi Co, Philip Morris) are supported by dominant models of economic prosperity orientated towards greater consumption and an emphasis on 'value-adding' (eg, processing foods), moving raw material from poorer to wealthier countries (and often processed material back to poorer countries). These models often treat negative impacts on environment, health and social well-being as externalities to be corrected using financial calculations rather than critical outcomes that should be incorporated into metrics for assessing the 'success' of efforts towards economic growth. ${ }^{24}{ }^{25}$ These approaches assume-incorrectly, as we have learnt - that increased productivity and technological progress will automatically yield better social outcomes for all. ${ }^{26}$

These narrow economic models have benefited the alcohol, tobacco and food industries financially, enabling massive horizontal and vertical integration and the creation of huge multinational companies. This has facilitated their position as powerful (and often 'essential') stakeholders in the eyes of economic policy-makers. ${ }^{10}$ However, the distributional benefits of their business 
model are limited, resulting in both massive concentration of capital at the corporate centre and minimal economic benefit and numerous harms at the societal level. The income differential between executives of tobacco companies and leaf producers is a dramatic example: executives of 'big tobacco' earn close to US $\$ 16$ million per year while tobacco growers in countries like Malawi barely cover their costs of production and often operate at a loss. ${ }^{27}$ In addition to the concentration of capital among the few, these industries have also benefited from the long-term disregard for health and environmental considerations by governments. Constrained domestic policy autonomy has limited the ability of governments to legislate to address the detrimental impacts of these industries on the health of populations ${ }^{28} 29$ and on the environment. ${ }^{30}$ The tobacco, processed food and alcohol industries have consistently positioned themselves as key stakeholders in policy deliberation, and on this basis have very effectively opposed regulation to limit production and consumption of these commodities, including successful contestation in domestic courts and international trade and investment forums. ${ }^{31} 32$

\section{SHIFTING MANDATES}

Despite these problematic outcomes, the mandates of the economic sectors of government have largely been to support these industries by offering investment incentives and infrastructure supports, ${ }^{33}{ }^{34}$ and ensuring minimal regulations on their products and practices. ${ }^{6}$ However, there is growing recognition among economists and policy-makers that this narrow approach to economic development is fraught with problems. In part, this recognition is a result of rising inequality and evidence of environmental harms generated by current modes of production. ${ }^{35}{ }^{36}$ Sentiments once reserved for critics of the policies of the IMF, viewed as a bastion for controversial neoliberal approaches to economics, are being published in mainstream economic journals and espoused by the IMF itself. ${ }^{37}$ These include an explicit rejection of the idea that government is simply a protector of the market rather than regulator of consumer choice ${ }^{38}$, calls to review economic policy approaches to reduce inequalities and negative impacts on vulnerable groups, ${ }^{39}$ and development of strategies to support an accounting of environmental impacts. ${ }^{40}$ This shift is even being witnessed in large investment funds, some of whom are making the decision to divest from tobacco, alcohol and some food companies based on the social harm caused by these companies and not simply return on investment. ${ }^{4-43}$ This perspective is stated forcefully by leaders like Jacinda Arden, the Prime Minister of New Zealand, who at a recent high-level meeting on the Sustainable Development Goals (SDGs) noted, 'Economic growth accompanied by worsening social outcomes is not success. It is failure'. ${ }^{44}$ This shift is also expressed by an expanding group of prominent economists who advance an 'inclusive prosperity' agenda that takes into account 'human prosperity broadly, including non-pecuniary sources of well-being, from health to climate change to political rights', and categorically rejects a 'market fundamentalism'. ${ }^{20}$

National development plans are also reflecting this shift towards the integration of sustainability and social goals alongside economic objectives. For example, in recent development plans in tobacco-producing countries, we see expressions of the need to transition from tobacco production towards more sustainable and healthy agricultural commodities. ${ }^{45}$ The expressed need for agricultural diversification in addition to and beyond tobacco reflects the numerous considerations policymakers are now attempting to integrate, from economics to environment to health. Although these development objectives still find themselves misaligned with many economic policies, ${ }^{45} 46$ the presence of these goals represent an important shift in mandates. We are seeing what Grabel refers to as 'productive incoherence ${ }^{39}$; divergent discourses on how governments should approach economic development, even within government sectors, and their relationship to the market. These shifts have been productive because they challenge the notion that the role of government is to 'balance' economic growth with other social goods, encouraging rather a critical interrogation of whether economic mandates contribute to broader social goods and if not, how these mandates can be shifted to achieve social and environmental ends.

Pivotal to effective regulation of unhealthy commodities will be the inculcation of whole-of-government mandates related to healthy and sustainable economic activity into tangible 'key performance indicators' (KPIs). On the economic side, inclusion of the protection of public health explicitly into KPIs will support consideration of health in strategies to promote economic sustainability, livelihoods and employment. The World Bank's Human Capital Project and associated Index offer a tangible example of the potential to revision indicators of success across sectors. ${ }^{47}$ In relation to nutrition, the Index positions investment in the best-practice early child nutrition interventions as a key strategy to develop a healthy and productive future workforce, and thus as a necessary prerequisite for future economic development. This World Bank project is one important example of how the concern for social and environmental well-being is being integrated and encouraged in policy domains that have historically been more narrowly market oriented.

Another example are the investment cases for tobacco control developed by UNDP and the Framework Convention Secretariat in partnership with country governments, which they began releasing in late 2019. These country-level analyses assess the economic burden of tobacco-associated diseases and the economic benefits of strong taxation measures. Although these cases use economic framing to justify policy measures aimed at preventing NCDs, they also serve to engage the economic sector in a whole-of-government mandate for development. These examples illustrate the potential for public 
health advocates to support the economic sector in policy development by investigating the potential economic impact of health policies from an equity perspective, both positive (eg, future workforce) and negative (eg, short-term impacts on producers of commodities that are being phased out). ${ }^{48}$ This would then support the codesign of policies related to food, alcohol and tobacco supply that would address health concerns and also mitigate or compensate for the necessary economic 'cost' of reducing these commodities, particularly for those who lose in the short term.

\section{INSTITUTIONAL INNOVATION}

The potential generated by shifting mandates in the economic sector shows promise for deeper coherence between the aims of the health sector in fostering healthy product environments and those of the economic sector for sustainable economic development. The ideal for the public health community is a coherence that is based on 'basic ideas ${ }^{49}$ or "core beliefs' ${ }^{50}$ The shift in mandates must be combined with new institutions that can move these mandates into policy and programming. For example, tobacco-producing countries have longstanding institutional arrangements that facilitate the supply of tobacco. The web of auction houses, governing boards, agricultural research supports specific to tobacco, among others all serve to entrench tobacco supply in the actual economy of the country. ${ }^{51}{ }^{52}$ In this way, there are real economic implications to shift away from such a commodity. This institutional entrenchment results in the continuation of the economic problems or limitations arising from a reliance on tobacco. For example, it is now widely demonstrated that tobacco farmers make very little from tobacco growing but have limited alternatives due to the historical and institutional entrenchment of the crop in the agricultural sector. ${ }^{27} 53$ Similar analysis examining the economic benefits and costs of sugar tax in Zambia illustrates that change in consumption has implications for the economics of production. ${ }^{54}$ The challenge becomes how to reconfigure institutions to support a healthy product supply and fill the void left by reductions in the supply of unhealthy commodities.

Innovation in the institutional space, in terms of the rules, norms and strategies that frame action, is a perplexing challenge. There is a critical need to expand the scholarship on institutional innovation to examine how new ideas and approaches to government coordination and cooperation can 'disrupt the common wisdom and habitual practices that hitherto dominated the solution context' ${ }^{55}$ What is important to note is that often the solution context is characterised by silos working towards conflicting policy objectives, as is the case when the economic sector is incentivising investment by unhealthy commodity producers while the health sector tries to control the same producers.

One experiment in institutional innovation that is being implemented in countries around the world is the intersectoral coordinating mechanism, which brings together different sectors of government to implement the WHO Framework Convention on Tobacco Control (FCTC) ${ }^{56}$ This approach establishes spaces where sectors come together to coordinate the development and implementation of shared mandates. An important implication of our analytical lens is that unlike approaches that seek to use these forums to enlist the support from economic sectors for predetermined health plans, we advocate for health actors to use these spaces to pursue constructive deliberation. Deliberation creates new mandates that integrate sustainable, health-promoting, economy-contributing considerations in product and industry management from supply through to demand measures. Certainly, this will sound utopian to some, but as we argue here, there is (or certainly will be as we continue to come closer to the limits of current modes of production) a shift in government priorities driven by a convergence of public advocacy and international planning that reflects a strong critique of the status quo. ${ }^{57}$ Importantly, what we are demonstrating is that beyond utopian vision, organisations and governments are currently pursuing new approaches to policy coherence across sectors as exemplified by recent work at the Pan-American Health Organization, ${ }^{58} \mathrm{UNDP}^{59}$ and the Food and Agricultural Organization of the United Nations (FAO) whose director general has signalled that the role of the FAO is not simply to address hunger, but to work with governments to ensure a healthy food supply. ${ }^{60}$ What will be important is to foster this constructive deliberation within government, while continuing to monitor, scrutinise and publicise industry power over such institutional arrangements, a power that has been so detrimental to progress towards healthy product environments. ${ }^{61}$

There are several opportunities that this analysis identifies, to achieve product regulation and healthy product supports that align with multiple relevant government objectives. First, there is a need to pool resources for intersectoral work. Often resources are dedicated within ministries and departments making it difficult to mobilise resources for joint programming, or even regular intersectoral coordinating meetings to foster dialogue across sectors. ${ }^{62}$ Another consideration is the need to implement communication and information channels across sectors. It is important to pool information about relevant legislation and regulations across sectors. For example, our own work in tobacco-producing countries finds that often departments of agriculture have little evidence on the economic livelihoods of tobacco farmers and often rely on industry narratives of prosperity for decision-making. The same is true about rates of tobacco consumption within country, which has bearing on justifications to support tobacco production based on the received wisdom that tobacco is primarily an export commodity and is not a health consideration within country. ${ }^{45}$ There is a need to expand the types of information available to sectors beyond what might be historically narrowly focused on economic indicators of production or sales to include environmental impact of supply chains, health indicators 
linked to consumption and others. One important aspect of coordination is to have regular and mandated communication across sectors towards mandates that are developed around intersectoral working. This has been achieved in many countries through intersectoral coordinating mechanisms for tobacco control and food regulation. ${ }^{563}$ For example, in 2010, the government of Mexico established a National Agreement for Nutritional Health which brought together heads of 15 different government agencies to pursue healthy food policy. The institutional arrangement resulted in important advancements including a school food policy that restricted access to processed foods and provided greater access to healthy foods, and a programme by the Secretariat on Law and Labour focused on healthy food for workers. ${ }^{64}$

\section{CONCLUSION}

Crude mandates of economic growth have made it difficult to control unhealthy commodity industries to achieve public health outcomes. These mandates at once served a willfull neglect of industry regulation while mobilising policy that fostered the growth of these industries. Recent shifts in notions of 'good' economic policy provide an important window of opportunity for the health sector to work across government to reimagine policy mandates and institutional forms. The challenge faced by health advocates in enlisting the economic sector in regulating alcohol, tobacco and processed foods has been the position these industries have had as contributors to economic growth in the eyes of government. In a new era where climate change and inequality are challenging the status quo of economic growth as the ultimate end of economic policy, there is more room for the health sector to build bridges with the economic sector. These bridges must involve the coconstruction of creative new mandates that explicitly move support away from unhealthy commodity-producing industries towards sustainable and healthy consumer products and modes of production. In particular, there are opportunities for public health advocates to use intersectoral forums to pursue constructive deliberation on the integration of sustainable, health-promoting, economy-contributing product and industry management, and to develop new streams of financing for policy activities that achieve multiple whole-of-government objectives.

Contributors Both authors developed the idea for the manuscript, revised subsequent drafts and contributed to the conceptual and scholarly development of the final version and approve the final version. RL developed the first partial draft. AMT added content towards the first full draft.

Funding This study was funded by Fonds de Recherche Sante Quebec (Junior 1 Career Award). RL was a fellow at the Sydney Social Sciences and Humanities Research Centre at the University of Sydney at the time of writing this paper.

Competing interests None declared.

Patient consent for publication Not required.

Provenance and peer review Not commissioned; externally peer reviewed.

Data availability statement There are no data in this work
Open access This is an open access article distributed in accordance with the Creative Commons Attribution Non Commercial (CC BY-NC 4.0) license, which permits others to distribute, remix, adapt, build upon this work non-commercially, and license their derivative works on different terms, provided the original work is properly cited, appropriate credit is given, any changes made indicated, and the use is non-commercial. See: http://creativecommons.org/licenses/by-nc/4.0/.

\section{ORCID iD}

Raphael Lencucha http://orcid.org/0000-0002-9273-2027

\section{REFERENCES}

1 Hawkins B, Holden C, Eckhardt J, et al. Reassessing policy paradigms: a comparison of the global tobacco and alcohol industries. Glob Public Health 2018;13:1-19.

2 Moodie R, Stuckler D, Monteiro C, et al. Profits and pandemics: prevention of harmful effects of tobacco, alcohol, and ultraprocessed food and drink industries. Lancet 2013;381:670-9.

3 Brownell KD, Warner KE. The perils of ignoring history: big tobacco played dirty and millions died. How similar is big food? Milbank $Q$ 2009;87:259-94.

4 Lencucha R, Dubé L, Blouin C, et al. Fostering the catalyst role of government in advancing healthy food environments. Int $\mathrm{J}$ Health Policy Manag 2018;7:485-90.

5 Allen LN, Nicholson BD, Yeung BYT, et al. Implementation of non-communicable disease policies: a geopolitical analysis of 151 countries. Lancet Glob Health 2020;8:e50-8 http://www. sciencedirect.com/science/article/pii/S2214109X19304462

6 Sharma LL, Teret SP, Brownell KD. The food industry and selfregulation: standards to promote success and to avoid public health failures. Am J Public Health 2010;100:240-6.

7 Peck J, Theodore N, Brenner N. Postneoliberalism and its Malcontents. Antipode 2010;41:94-116.

8 BrownW. In the ruins of neoliberalism: the rise of antidemocratic politics in the West. New York, NY: Columbia University Press, 2019.

9 Lang A. World trade law after Neoliberalism: Reimagining the global economic order. Oxford University Press, 2011: 416.

10 Lencucha R, Thow AM. How Neoliberalism is shaping the supply of unhealthy commodities and what this means for NCD prevention. Int $J$ Health Policy Manag 2019;8:514-20.

11 Kickbusch I, Allen L, Franz C. The commercial determinants of health. Lancet Glob Health 2016;4:e895-6.

12 McKee M, Stuckler D. Revisiting the corporate and commercial determinants of health. Am J Public Health 2018;108:1167-70.

13 World Health Organization. Addressing and managing conflicts of interest: In the planning and delivery of nutrition programmes at country level [Internet]. Geneva: World Health Organization, 2016. https://apps.who.int/iris/bitstream/handle/10665/206554/ 9789241510530_eng.pdf?sequence=1

14 Gasser A, Sessou L, Goma F, et al. International Labour Organization (ILO) ends tobacco industry funding [Internet]. Blog - Tobacco Control, 2019. Available: https://blogs.bmj.com/tc/2019/12/01/ world-international-labour-organization-ilo-ends-tobacco-industryfunding/

15 WHO. GCM/NCD launches new Community of Practice on NCDs and Commercial Determinants of Health [Internet]. Available: http:// www.who.int/global-coordination-mechanism/news/launch-newcommunity-of-practice-on-NCDs-and-determinants/en/

16 de Leeuw E. Engagement of sectors other than health in integrated health governance, policy, and action. Annu Rev Public Health 2017;38:329-49.

17 United Nations Development Programme. Responding to the challenge of non-communicable diseases. New York, USA: United Nations Development Programme, 2019.

18 Mounsey S, Veerman L, Jan S, et al. The macroeconomic impacts of diet-related fiscal policy for NCD prevention: a systematic review. Econ Hum Biol 2020;37:100854.

19 Labonté R. Neoliberalism 4.0: The Rise of Illiberal Capitalism Comment on "How Neoliberalism Is Shaping the Supply of Unhealthy Commodities and What This Means for NCD Prevention". Int J Health Policy Manag 2020;9:175-8.

20 Naidu S, Rodrick D, Zucman G. Economics after neoliberalism. Boston, MA: MIT Press, 2019: 9-29.

21 Brenner N, Peck J, Theodore N. After Neoliberalization? Globalizations 2010;7:327-45.

22 Sadeghirad B, Duhaney T, Motaghipisheh S, et al. Influence of unhealthy food and beverage marketing on children's dietary intake and preference: a systematic review and meta-analysis of randomized trials. Obes Rev 2016;17:945-59. 
23 Kelly B, King L, Baur L, et al. Monitoring food and non-alcoholic beverage promotions to children. Obes Rev 2013;14(Suppl 1):59-69.

24 Belesova K, Kelman I, Boyd R. Governance through economic paradigms: addressing climate change by accounting for health PaG 2016;4:87-96.

25 Porter ME, Kramer MR. Creating Shared Value. In: Lenssen GG, Smith NC, eds. Managing Sustainable Business: An Executive Education Case and Textbook [Internet]. Dordrecht: Springer Netherlands, 2019: 323-46.

26 Gilbert J, Lennox C. Towards new development paradigms: the United Nations Declaration on the rights of Indigenous peoples as a tool to support self-determined development. Int J Hum Rights 2019;23:104-24

27 Makoka D, Drope J, Appau A, et al. Costs, revenues and profits: an economic analysis of smallholder tobacco farmer livelihoods in Malawi. Tob Control 2017;26:634-40.

28 Baker P, Friel S, Schram A, et al. Trade and investment liberalization, food systems change and highly processed food consumption: a natural experiment contrasting the soft-drink markets of Peru and Bolivia. Global Health 2016;12:24.

29 Thow AM, Reeve E, Naseri T, et al. Food supply, nutrition and trade policy: reversal of an import ban on turkey tails. Bull World Health Organ 2017:95:723-5.

30 Lecours $\mathrm{N}$. The Harsh realities of tobacco farming: a review of socioeconomic, health and environmental impacts. In: Tobacco control and tobacco farming: separating myth from reality. Ottawa, ON: Anthem Press (IDRC), 2014.

31 Thow AM, Jones A, Hawkes C, et al. Nutrition labelling is a trade policy issue: lessons from an analysis of specific trade concerns at the world trade organization. Health Promot Int 2018;33:561-71.

32 Mitchell A, Voon T. Implications of the World Trade Organization in combating non-communicable diseases. Public Health 2011;125:832-9.

33 Labonté R, Lencucha R, Goma F, et al. Consequences of policy incoherence: how Zambia's post-FCTC investment policy stimulated tobacco production. J Public Health Policy 2019;40:286-91.

34 Lencucha R, Drope J, Labonte R, et al. Investment incentives and the implementation of the framework convention on tobacco control: evidence from Zambia. Tob Control 2016;25:483-7.

35 Georgieva K. IMF Managing Director's Statement to the Development Committee, October 2019 [Internet]. International Monetary Fund, 2019. Available: https://www.imf.org/en/ Publications/Policy-Papers/Issues/2019/10/19/mdwritten-statementto-development-committee-october-19-2019

36 Dabla-Norris E, Kochhar K, Suphaphiphat N, et al. Causes and consequences of income inequality: a global perspective. Report No: SDN/15/13. International Monetary Fund, 2015.

37 Stiglitz JE. Globalization and its discontents. W. W. Norton, 2003: 305.

38 Ostry JD, Loungani P, Furceri D. Neoliberalism: Oversold? Finance Dev Wash 2016;53:38-41.

39 Grabel I. Not your grandfather's IMF: global crisis, 'productive incoherence' and developmental policy space. Cambridge $J$ Econ 2011;35:805-30

40 Fritz M, Koch M. Economic development and prosperity patterns around the world: structural challenges for a global steady-state economy. Global Environ Change 2016;38:41-8.

41 MacAskill W. Does Divestment Work? The New Yorker [Internet] 2015. Available: https://www.newyorker.com/business/currency/ does-divestment-work

42 Marriage M. Pension funds review tobacco divestment. Financial Times [Internet], 2016. Available: https://www.ft.com/content/ e87a9b3c-0708-11e6-9b51-0fb5e65703ce

43 McKibben B. Divestment works - and one huge bank can lead the way. The Guardian [Internet], 2019. Available: https://www. theguardian.com/commentisfree/2019/oct/13/divestment-bankeuropean-investment-fossil-fuels

44 McCarthy J. Jacinda Ardern Says economic growth is pointless if people aren't thriving. Global Citizen [Internet], 2019. Available: https://www.globalcitizen.org/en/content/jacinda-arderngoalkeepers-unga-2019/

45 Lencucha R, Reddy SK, Labonte R, et al. Global tobacco control and economic norms: an analysis of normative commitments in Kenya, Malawi and Zambia. Health Policy Plan 2018;33:420-8.

46 Kulik MC, Bialous SA, Munthali S, et al. Tobacco growing and the sustainable development goals, Malawi. Bull World Health Organ 2017;95:362-7.

47 World Bank. Human capital project [Internet]. Available: https://www. worldbank.org/en/publication/human-capital

48 Lencucha R, Pal NE, Appau A, et al. Government policy and agricultural production: a scoping review to inform research and policy on healthy agricultural commodities. Global Health 2020;16:11

49 Nordbeck R, Steurer R. Multi-sectoral strategies as dead ends of policy integration: lessons to be learned from sustainable development. Environ Plann C Gov Policy 2016;34:737-55.

50 Sabatier PA. An advocacy coalition framework of policy change and the role of policy-oriented learning therein. Policy Sci 1988;21:129-68.

51 Smith J, Lee K. From colonization to globalization: a history of state capture by the tobacco industry in Malawi. Rev Afr Polit Econ 2018;45:186-202.

52 Prowse M, Tobacco GP. Transformation and development dilemmas from central Africa. Switzerland: Palgrave Macmillan, 2020.

53 Magati P, Lencucha R, Li Q, et al. Costs, contracts and the narrative of prosperity: an economic analysis of smallholder tobacco farming livelihoods in Kenya. Tob Control 2019;28:268-73.

54 Hangoma P, Surgey G. Contradictions within the SDGs: are sin taxes for health improvement at odds with employment and economic growth in Zambia. Global Health 2019;15:1-9.

55 Torfing J. Collaborative innovation in the public sector: the argument. Public Manag Rev 2019;21:1-11.

56 Drope J, Lencucha R, Magati P, et al. Tobacco control governance in sub-Saharan Africa: Implementing Article 5.2(a) of the World Health Organization Framework Convention on Tobacco Control. New York, NY: UNDP and WHO FCTC Convention Secretariat, 2016.

57 Monni S, Pallottino M. Beyond growth and development: buen vivir as an alternative to current paradigms. Int $J$ Environ Policy Decis Mak 2015;1:184.

58 Becerra-Posada F. Health in all polices: a strategy to support the sustainable development goals. Lancet Glob Health 2015;3:e360.

59 Gopinathan U, Watts N, Lefebvre A, et al. Global governance and the broader determinants of health: a comparative case study of UNDP's and WTO's engagement with global health. Glob Public Health 2019:14:175-89.

60 Graziano da Silva J. 160th FAO Council - opening [Internet]. Rome, Italy: FAO Council Meeting, 2018. http://www.fao.org/directorgeneral/former-dg/da-silva/my-statements/detail/en/c/1173595/

61 Miller D, Harkins C. Corporate strategy, corporate capture: food and alcohol industry lobbying and public health. Crit Soc Policy 2010;30:564-89.

62 Peters BG. Managing horizontal government: the politics of coordination. Public Adm 1998;76:295-311.

63 Thow AM, Greenberg S, Hara M, et al. Improving policy coherence for food security and nutrition in South Africa: a qualitative policy analysis. Food Secur 2018;10:1105-30.

64 Pan American Health Organization. Advancing the health in all policies approach in the Americas: what is the health sector's role? Washington, DC: Pan American Health Organization, 2015. 